\title{
Are fish oil omega-3 long-chain fatty acids and their derivatives peroxisome proliferator-activated receptor agonists? Osman ABSM Gani
}

\author{
Address: Department of Pharmacology, Institute of Medical Biology, Faculty of Medicine, University of Tromsø, 9037 Tromsø, Norway
}

Email: Osman ABSM Gani - Osman.Gani@fagmed.uit.no

Published: 20 March 2008

Cardiovascular Diabetology 2008, 7:6 doi:10.1186/1475-2840-7-6

This article is available from: http://www.cardiab.com/content/7/1/6

(c) 2008 Gani; licensee BioMed Central Ltd.

This is an Open Access article distributed under the terms of the Creative Commons Attribution License (http://creativecommons.org/licenses/by/2.0), which permits unrestricted use, distribution, and reproduction in any medium, provided the original work is properly cited.
Received: 8 March 2008

Accepted: 20 March 2008

\begin{abstract}
Background: Peroxisome proliferator-activated receptors (PPAR $\alpha, \operatorname{PPAR} \gamma$, and PPAR $\delta$ ) are physiological sensors for glucose and lipid homeostasis. They are also the targets of synthetic drugs; such as fibrates as PPAR $\alpha$ agonists which lower lipid level, and glitazones as PPAR $\gamma$ agonists which lower glucose level. As diabetes and metabolic diseases are often associated with high blood glucose and lipid levels, drugs that activate both PPAR $\alpha / \gamma$ would be a logical approach. But synthetically developed PPAR $\alpha / \gamma$ dual agonists and glitazones are showing side effects such as weight gain and edema. Therefore, natural compounds and their close derivatives are focused as future drugs against metabolic diseases.

Presentation of hypothesis: Docosahexaenoic acid and eicosapentaenoic acid, which are the fatty acids abundant in fish oil, are traditionally used against metabolic diseases. These fatty acids act as PPAR agonists that transcript the genes involved in glucose and lipid homeostasis. Present hypothesis suggests that the derivatives of these fatty acids are stronger PPAR agonists than the parent compounds. X-ray structures of PPARs indicate that $\alpha$ or $\beta$ derivatives of fatty acids would fit into PPAR $\alpha / \gamma$ binding cavity. Therefore, the derivatives will exhibit stronger affinities and activities than the parent compounds.

Testing of the hypothesis: Ligand binding assays and gene transactivation assays should be performed to test the hypothesis. Fluorescence-based methods are advantageous in binding assays, because they were found more suitable for fatty acid binding assays. In transactivation assays, care should be taken to remove contaminants from recombinant proteins.

Implications of the hypothesis: Present hypothesis is framed on the basis of molecular structure of natural PPAR agonists. Small structural changes in the molecular structure of fatty acids have a great influence on activating different PPARs. Therefore, this hypothesis bridges the concept of natural PPAR agonists and the use of structural information in designing new drugs against diabetes and metabolic syndrome. The derivatives may also be used as anti-inflammatory and anticancer agents.
\end{abstract}

\section{Background}

Peroxisome proliferator-activated receptors (PPARs) are members of nuclear receptor superfamily. Three isotypes of PPARs (PPAR $\alpha$, PPAR $\gamma$, and PPAR $\delta$ ) have distinct tissue distributions, distinct physiological roles, and distinct ligand specificities [1]. Activation of PPAR $\alpha$ lowers lipid lev- 
els, PPAR $\gamma$ increases insulin sensitivity, and PPAR $\delta$ regulates cholesterol and glucose levels [1-3]. PPAR ligands comprise natural or synthetic compounds, including fatty acids and eicosanoids $[4,5]$. As synthetic compounds, fibrates are known as PPAR $\alpha$ agonists and glitazones act as PPAR $\gamma$ agonists [2] (Fig. 1). PPAR $\alpha / \gamma$ dual agonists have also been developed, because type 2 diabetes and metabolic syndrome are often associated with high lipid and glucose level in blood.

Antidiabetic glitazones exhibit side effects such as weight gain, edema, and increased risk of myocardial infarctions

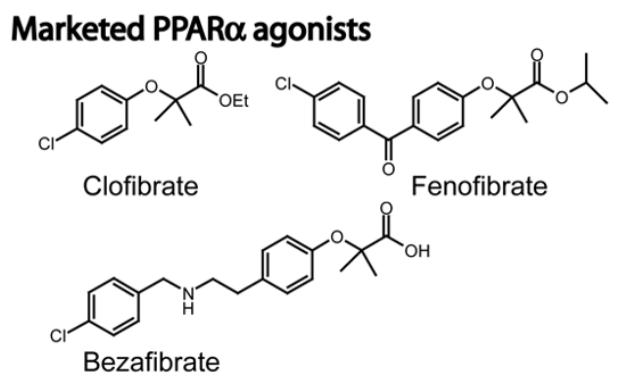

\section{Marketed PPAR $\gamma$ agonists}
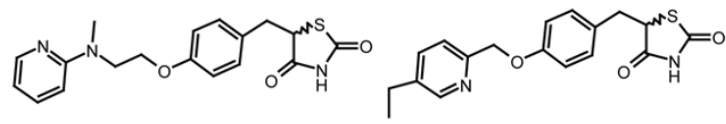

5(R/S)-Rosiglitazone 5(R/S)-Pioglitazone

PPAR p partial agonist
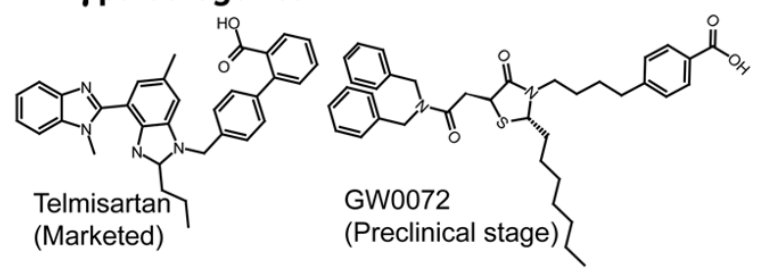

Investigational PPAR $\alpha / \gamma$ dual agonists



Fatty acid derivatives as future PPAR $\alpha / \gamma$ dual agonists
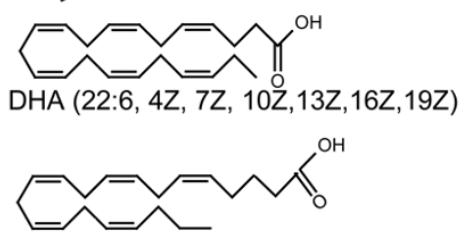

EPA (20:5, 5Z, 8Z, 11Z,14Z,17Z)

Figure I

PPAR agonists.
$[6,7]$, which have limited the use of these drugs in diabetic patients with high lipid levels. The PPAR $\alpha / \gamma$ dual agonists, which reached clinical trials, have been suspended for safety issues [8]. Although much information is not available, these dual agonists are believed to exhibit similar side effects as with glitazones [2,9]. Bezafibrate, a traditional PPAR $\alpha$ agonist, has recently been identified as a safe and synthetic pan agonist for all PPAR isotypes $[10,11]$, although with relatively low potency and low affinity (Kd $\sim 5 \mu \mathrm{M}$ for PPAR $\delta[5]$ ).

Development of drugs from natural origin against chronic diseases, such as metabolic syndrome and diabetes, has gain focus recently. Because metabolic system can easily excrete biomolecules and their derivatives, thereby avoid undesirable effects. Fish oil, which contains docosahexaenoic acid (DHA) and eicosapentaenoic acid (EPA), is traditionally used as functional food against metabolic diseases. These beneficial health effects of DHA and EPA are thought to arise from their binding and activating PPARs $[12,13]$. Phytanic acid, a natural PPAR agonist from human diet, has also been shown to enhance glucose uptake and thereby increases insulin sensitivity, however with less capacity to differentiate adipocytes [14]. A recent study has reported an extract of Fuligo candida, Fuligocandin $B$, to induce 15 -deoxy- $\Delta^{12,14}$ prostaglandin $\mathrm{J}_{2}$ $\left(15 \mathrm{~d}-\mathrm{PGJ}_{2}\right)$, which is the most potent endogenous PPAR $\gamma$ ligand $[15,16]$.

The hypothesis of this article is drawn on the assumption of PPAR $\alpha / \gamma$ dual agonists from naturally originated molecules, that the derivatives of DHA and EPA would show stronger affinities for PPARs than the parent compounds. Therefore, these compounds may be used as putative drugs against diabetes and metabolic syndrome.

\section{Presentation of hypothesis}

The hypothesis is based on (a) functional roles of PPARs - PPAR agonists reduce blood glucose and lipid levels, and (b) structural details of ligand binding cavity of PPARs, which suggest how a ligand fits into the cavity.

\section{Functional roles of PPARs}

PPARs perform their activities by endogenous ligands produced by metabolism of fatty acids. Unmetabolized fatty acids can also act as PPAR ligands. Activities of these ligands vary according to their binding specificities for different PPARs, and on distributions of these ligands in different organs [17]. Because of this diversity, not all endogenous PPAR ligands are characterized yet. However, PPAR activities can be summarized as lipid sensors by their complementary actions. PPAR $\alpha$ is expressed mainly in the tissues with high capacity for fatty acid oxidations, e.g. liver, heart, skeletal muscle etc. On the other hand, PPAR $\gamma$ is expressed predominantly in the adipose tissue but is 
also expressed in immune and inflammatory cells, mucosa of the colon and placenta. If the fatty acid concentrations are increased, PPAR $\alpha$ uptakes and oxidizes fatty acids and their metabolites [18], and PPAR $\gamma$ enhances storage of fatty acids in the adipose tissue [19]. These combined activities of PPAR $\alpha$ and PPAR $\gamma$ cause increased utilization of glucose than fatty acids in the skeletal muscles, and cause enhanced insulin sensitivity (Fig. 2). Although
PPAR $\delta$ 's role is not well defined, it is also implicated for fatty acid oxidation [20].

\section{Structure of PPARs}

Like other nuclear receptors, 3D structure PPARs consists of a DNA binding domain in the N-terminus and a ligand binding domain (LBD) in the C-terminus [21]. In canonical mechanism, ligand binding to PPARs causes conformational changes in the receptor, which release

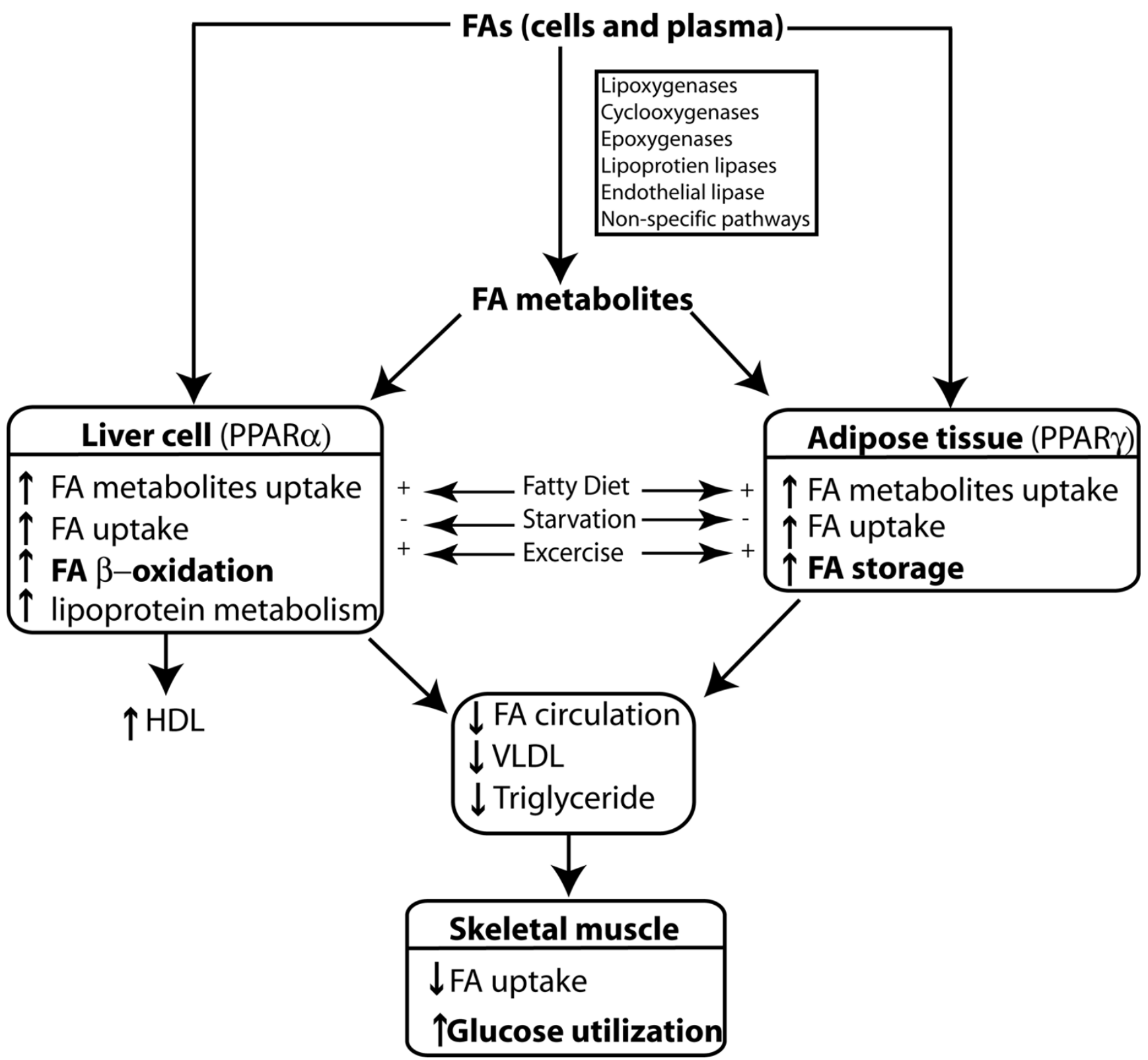

Figure 2

Complementary actions of PPAR $\alpha$ and PPAR $\gamma$. PPAR $\alpha$ oxidizes fatty acids in the liver cells, and PPAR $\gamma$ stimulates storage of fatty acids in the adipose tissues. Major events are shown in bold fonts. FA = fatty acid; HDL = High-density lipoprotein; VLDL = very low-density lipoprotein. 
corepressor and recruit coactivator. Then the receptors form compulsory heterodimers with another nuclear receptor, named retinoid X-receptor (RXR), and the resulting complex finally bind to DNA of target genes [22] (Fig. 3).

To date, 37 X-ray crystallographically determined structures of PPAR-LBDs are deposited in the Protein Data Bank (PDB) in different apo- and holo forms. These structures shows that the LBD is composed of 13 helices and a small four-stranded $\beta$-sheet (Fig. 3B). The lower part of LBD contains a Y-shaped cavity with the volume of 1300-1400 $\AA^{3}$ for ligand binding. This cavity includes 34 amino acids; each arm of the cavity is $\sim 12 \AA$ in length. One of the arms is hydrophilic but the other two are hydrophobic. While the amino acids in the polar arm form H-bonds with the ligand polar atoms, those in the hydrophobic arms form non-specific interactions with hydrophobic part of the ligands. Across PPARs, 80\% amino acids in the cavity are conserved, and the overall size of the cavity is also similar [23]. However, the topology is different inside the cavities of different PPARs. These differences influence ligand specificities. Ligand binding stabilizes the LBD in the active conformation; as such coactivator and RXR can bind to the activated LBD [24].

\section{Fatty acids and their derivatives as PPAR agonists}

For centuries, consumption of fatty fish is considered to protect against metabolic diseases. During early 1970s, Danish physicians discovered that Greenland Eskimos consuming fatty fishes exhibited low incidence of heart diseases and arthritis despite high-fat diet. This finding suggested beneficial effects of DHA and EPA. Fish oil supplementation successfully passed clinical trials and is now effectively used for treating metabolic syndrome [25].

Usually, PPAR ligands have three essential parts for optimal binding: (a) polar head group, (b) linker region, and (c) hydrophobic tail. DHA and EPA have a carboxylic group which serves as the polar head group, and their long chains form the required linker and hydrophobic regions. In addition, X-ray structures of PPARs show some free spaces proximal to the polar arm of binding cavity [26], and substitutions at $\alpha$ or $\beta$ positions on DHA and EPA would fit into these spaces. Specifically, hydrophobic sub-


Figure 3

Structure and functions of PPARs. (A) Functional domains of PPARs. DBD = DNA binding domain; LBD = ligand binding domain. Numbers denote residue identity in percent compared to PPAR $\alpha$. (B) LBD of PPARs. PPAR $\alpha$-LBD (PDB ID; II7G, chain $A$ ) is shown with secondary structures; helices in cylindrical form (H: red), $\beta$-strands (S: green), $3-10$ helix (light blue) and loops (cyan). The blue object shows ligand binding pocket. (C) Ligand-dependent activation of PPARs. 
stituents that complement the size of free spaces would be a choice. However, substituents may not fit into PPAR $\delta$ because of its narrow polar regions [27]. Size and hydrophobic/hydrophilic ratio of substituents may influence the ratio of binding between PPAR $\alpha$ and PPAR $\gamma$ [28]. A high PPAR $\alpha / \operatorname{PPAR} \gamma$ ratio of affinities of putative ligands would be safer dual agonists, because the side effects are thought to arise from high PPAR $\gamma$ affinity [2].

\section{Limitation of the hypothesis}

EPA and DHA have many beneficial health effects which are not typical for PPAR ligands. For example, their capacity to reduce coronary heart disease, blood pressure, primary heart attack and rheumatoid arthritis [29-31] are not observed with typical PPAR ligands. Also, various developmental problems including attention-deficit/hyperactivity disorder have been linked to biological deficiencies in polyunsaturated fatty acids [32]. But these fatty acids do not show many PPAR effects such as reversing insulin resistance $[33,34]$, which may occur due to dissociation between n-3 polyunsaturated fatty acid and lipid metabolism and insulin action in insulin resistant state [35]. Therefore, an interesting observation will be whether substitutions at $\alpha$ or $\beta$ positions on these fatty acids impart such typical PPAR effects.

\section{Testing of hypothesis}

Ligand binding assays and gene transactivation assays would confirm the hypothesis. Ligand binding assays quantify the binding affinities such as $\mathrm{Kd}$ or $\mathrm{IC}_{50}$ values. Previously published experiments with fatty acids showed inconsistent binding affinities. Krey et al.[5] reported binding affinities in 5-10 $\mu \mathrm{M}$ range, while Lin et al[36] reported this range of 5-17 $\mathrm{nM}$. The latter range corresponds to the intracellular free fatty acid concentrations which are in the range of 7-50 $\mathrm{nM}$ [37]. Until now, no data are available about the affinities of DHA, DHA derivatives, and EPA derivatives. Therefore, fluorescence-based methods as used by Lin et al. may provide correct binding affinities. In transactivation assays of PPAR $\alpha / \gamma$ genes, precautions should be taken to remove unwanted fatty acids in the recombinant proteins [38]. In both ligand binding and transactivation assays, ligands with high ratio of PPAR $\alpha / \gamma$ affinity and activity should be chosen, which mean that compounds showing less PPAR $\gamma$ affinities and activities would be ideal.

\section{Implication of the hypothesis}

The ligand binding cavity of PPARs is 3-4 times larger than the other nuclear receptors, indicating their capability to accommodate and bind variety of natural and synthetic lipophilic acids. Many previous studies have revealed the roles of natural PPAR agonists against specific diseases. For example, natural PPAR agonists such as $15 \mathrm{~d}$ $\mathrm{PGJ}_{2}$ are emerging as important regulators of immunity and inflammation [39-41]. 15d-PG) ${ }_{2}$ has also been implicated for antitumor activities [42]. PPAR $\alpha$ mediates the anti-inflammatory actions of palmitoylethanolamide, the naturally occurring amide of palmitic acid and ethanolamine [43]. Synthetic PPAR $\gamma$ agonists glitazones have been reported and used in phase I-II human clinical trials as anticancer agents [44].

Present hypothesis is framed on the basis of using natural PPAR agonists that small structural changes in the molecular structure of fatty acids have a great influence on activating different PPARs [45]. Therefore, this hypothesis bridges the concept of natural PPAR agonists and the use of structural information in designing new drugs against diabetes and metabolic syndrome. The derivatives may also be used as anti-inflammatory and anticancer agents.

\section{Abbreviations}

Peroxisome proliferator-activated receptors (PPARs); Docosahexaenoic acid (DHA); Eicosapentaenoic acid (EPA); Ligand binding domain (LBD); Retinoid X-receptor (RXR)

\section{Competing interests}

The author declares no competing interests.

\section{Acknowledgements}

I thank Professor Ingebrigt Sylte for revising the manuscript critically.

\section{References}

I. Willson TM, Brown PJ, Sternbach DD, Henke BR: The PPARs: from orphan receptors to drug discovery. J Med Chem 2000, 43(4):527-550.

2. Henke BR: Peroxisome proliferator-activated receptor alpha/ gamma dual agonists for the treatment of type 2 diabetes. J Med Chem 2004, 47(I7):4I I 8-4I 27

3. Barish GD, Narkar VA, Evans RM: PPAR delta: a dagger in the heart of the metabolic syndrome. J Clin Invest 2006, I I 6(3):590-597.

4. Kliewer SA, Sundseth SS, Jones SA, Brown PJ, Wisely GB, Koble CS, Devchand P, Wahli W, Willson TM, Lenhard JM, Lehmann JM: Fatty acids and eicosanoids regulate gene expression through direct interactions with peroxisome proliferator-activated receptors alpha and gamma. Proc Natl Acad Sci U S A 1997 , 94(9):43। 8-4323.

5. Krey G, Braissant O, L'Horset F, Kalkhoven E, Perroud M, Parker MG, Wahli W: Fatty acids, eicosanoids, and hypolipidemic agents identified as ligands of peroxisome proliferator-activated receptors by coactivator-dependent receptor ligand assay. Mol Endocrinol 1997, I I(6):779-79 I.

6. Nesto RW, Bell D, Bonow RO, Fonseca V, Grundy SM, Horton ES, Le Winter M, Porte D, Semenkovich CF, Smith S, Young LH, Kahn R: Thiazolidinedione use, fluid retention, and congestive heart failure: a consensus statement from the American Heart Association and American Diabetes Association. October 7, 2003. Circulation 2003, 108(23):294I-2948.

7. Nissen SE, Wolski K: Effect of rosiglitazone on the risk of myocardial infarction and death from cardiovascular causes. N Engl J Med 2007, 356(24):2457-247I.

8. Fievet C, Fruchart JC, Staels B: PPARalpha and PPARgamma dual agonists for the treatment of type 2 diabetes and the metabolic syndrome. Curr Opin Pharmacol 2006, 6(6):606-614.

9. Ferrara P, Gohlke H, Price DJ, Klebe G, Brooks CL 3rd: Assessing scoring functions for protein-ligand interactions. J Med Chem 2004, 47( I 2):3032-3047. 
10. Peters JM, Aoyama T, Burns AM, Gonzalez FJ: Bezafibrate is a dual ligand for PPARalpha and PPARbeta: studies using null mice. Biochim Biophys Acta 2003, I632(I-3):80-89.

II. Tenenbaum A, Motro M, Fisman EZ: Dual and pan-peroxisome proliferator-activated receptors (PPAR) co-agonism: the bezafibrate lessons. Cardiovasc Diabetol 2005, 4:I4.

12. Neschen S, Morino K, Dong J, Wang-Fischer Y, Cline GW, Romanell AJ, Rossbacher JC, Moore IK, Regittnig W, Munoz DS, Kim JH, Shulman GI: $\mathbf{n - 3}$ Fatty acids preserve insulin sensitivity in vivo in a peroxisome proliferator-activated receptor-alpha-dependent manner. Diabetes 2007, 56(4): 1034-104I.

13. von Schacky C: $\mathbf{n - 3}$ PUFA in CVD: influence of cytokine polymorphism. Proc Nutr Soc 2007, 66(2): 166-I70.

14. Heim M, Johnson J, Boess F, Bendik I, Weber P, Hunziker W, Fluhmann B: Phytanic acid, a natural peroxisome proliferator-activated receptor (PPAR) agonist, regulates glucose metabolism in rat primary hepatocytes. FASEB J 2002, 16(7):718-720.

15. Forman BM, Tontonoz P, Chen J, Brun RP, Spiegelman BM, Evans RM: I5-Deoxy-delta 12, I4-prostaglandin J2 is a ligand for the adipocyte determination factor PPAR gamma. Cell 1995 83(5):803-8I2.

16. Hasegawa $\mathrm{H}$, Yamada $Y$, Komiyama K, Hayashi M, Ishibashi M, Sunazuka T, Izuhara T, Sugahara K, Tsuruda K, Masuda M, Takasu N, Tsukasaki K, Tomonaga M, Kamihira S: A novel natural compound, a cycloanthranilylproline derivative (Fuligocandin B), sensitizes leukemia cells to apoptosis induced by tumor necrosis factor related apoptosis-inducing ligand (TRAIL) through 15-deoxy-Delta 12, I4 prostaglandin J2 production. Blood 2007, I I0(5): 1664-1674.

17. Evans RM, Barish GD, Wang YX: PPARs and the complex journey to obesity. Nat Med 2004, I0(4):355-36I.

18. Vu-Dac N, Schoonjans K, Kosykh V, Dallongeville J, Fruchart JC Staels B, Auwerx J: Fibrates increase human apolipoprotein AII expression through activation of the peroxisome proliferator-activated receptor. J Clin Invest 1995, 96(2):74|-750.

19. Rosen ED, Walkey CJ, Puigserver P, Spiegelman BM: Transcriptional regulation of adipogenesis. Genes Dev 2000, I 4(II): I 293-I 307.

20. Wang YX, Lee CH, Tiep S, Yu RT, Ham J, Kang H, Evans RM: Peroxisome-proliferator-activated receptor delta activates fat metabolism to prevent obesity. Cell 2003, I I3(2): I59-I70.

21. Mangelsdorf DJ, Thummel C, Beato M, Herrlich P, Schutz G, Umesono K, Blumberg B, Kastner P, Mark M, Chambon P, Evans RM: The nuclear receptor superfamily: the second decade. Cell 1995 , 83(6):835-839.

22. Keller H, Dreyer C, Medin J, Mahfoudi A, Ozato K, Wahli W: Fatty acids and retinoids control lipid metabolism through activation of peroxisome proliferator-activated receptor-retinoid X receptor heterodimers. Proc Natl Acad Sci U S A 1993 90(6):2160-2164.

23. Zoete V, Grosdidier A, Michielin O: Peroxisome proliferatoractivated receptor structures: Ligand specificity, molecular switch and interactions with regulators. Biochim Biophys Acto 2007.

24. Glass CK, Rosenfeld MG: The coregulator exchange in transcriptional functions of nuclear receptors. Genes Dev 2000, | 4(2): |2|-|4|.

25. Connor WE: Importance of $\mathbf{n - 3}$ fatty acids in health and disease. Am J Clin Nutr 2000, 7 I (I Suppl): I7IS-5S.

26. Sheu SH, Kaya T, Waxman DJ, Vajda S: Exploring the binding site structure of the PPAR gamma ligand-binding domain by computational solvent mapping. Biochemistry (Mosc) 2005, 44(4): I 193-1209.

27. Nolte RT, Wisely GB, Westin S, Cobb JE, Lambert MH, Kurokawa R, Rosenfeld MG, Willson TM, Glass CK, Milburn MV: Ligand binding and co-activator assembly of the peroxisome proliferatoractivated receptor-gamma. Nature 1998, 395(6698): |37-| 43 .

28. Cronet P, Petersen JF, Folmer R, Blomberg N, Sjoblom K, Karlsson U, Lindstedt EL, Bamberg K: Structure of the PPARalpha and gamma ligand binding domain in complex with AZ 242; ligand selectivity and agonist activation in the PPAR family. Structure 200I, 9(8):699-706.

29. Bucher HC, Hengstler P, Schindler C, Meier G: N-3 polyunsaturated fatty acids in coronary heart disease: a meta-analysis of randomized controlled trials. Am J Med 2002, I I 2(4):298-304.
30. Fortin PR, Lew RA, Liang MH, Wright EA, Beckett LA, Chalmers TC, Sperling RI: Validation of a meta-analysis: the effects of fish oil in rheumatoid arthritis. J Clin Epidemiol 1995, 48( I I): I 379-1390.

31. Morris MC, Sacks F, Rosner B: Does fish oil lower blood pressure? A meta-analysis of controlled trials. Circulation 1993, 88(2):523-533.

32. Sinn N, Bryan J: Effect of supplementation with polyunsaturated fatty acids and micronutrients on learning and behavior problems associated with child ADHD. I Dev Behav Pediatr 2007, 28(2):82-9|.

33. Manco M, Calvani M, Mingrone G: Effects of dietary fatty acids on insulin sensitivity and secretion. Diabetes Obes Metab 2004, 6(6):402-4I3

34. Mustad VA, Demichele S, Huang YS, Mika A, Lubbers N, Berthiaume $\mathrm{N}$, Polakowski J, Zinker B: Differential effects of $n-3$ polyunsaturated fatty acids on metabolic control and vascular reactivity in the type 2 diabetic ob/ob mouse. Metabolism 2006, 55(I0): I365-I374.

35. Podolin DA, Gayles EC, Wei Y, Thresher JS, Pagliassotti MJ: Menhaden oil prevents but does not reverse sucrose-induced insulin resistance in rats. Am J Physiol 1998, 274(3 Pt 2):R840-8.

36. Lin Q, Ruuska SE, Shaw NS, Dong D, Noy N: Ligand selectivity of the peroxisome proliferator-activated receptor alpha. Biochemistry (Mosc) 1999, 38(1): 185-190.

37. Hamilton JA: Fatty acid transport: difficult or easy? J Lipid Res I998, 39(3):467-48|.

38. Fyffe SA, Alphey MS, Buetow L, Smith TK, Ferguson MA, Sorensen MD, Bjorkling F, Hunter WN: Recombinant human PPAR-beta/ delta ligand-binding domain is locked in an activated conformation by endogenous fatty acids. J Mol Biol 2006, 356(4): $1005-1013$

39. Jiang C, Ting AT, Seed B: PPAR-gamma agonists inhibit production of monocyte inflammatory cytokines. Nature 1998, 39I (6662):82-86.

40. Ray DM, Akbiyik F, Bernstein SH, Phipps RP: CD40 engagement prevents peroxisome proliferator-activated receptor gamma agonist-induced apoptosis of B lymphocytes and B lymphoma cells by an NF-kappaB-dependent mechanism. J Immunol 2005, I 74(7):4060-4069.

4I. Ricote M, Li AC, Willson TM, Kelly CJ, Glass CK: The peroxisome proliferator-activated receptor-gamma is a negative regulator of macrophage activation. Nature 1998, 391 (6662):79-82.

42. Piva R, Gianferretti P, Ciucci A, Taulli R, Belardo G, Santoro MG: I5. Deoxy-delta 12,14-prostaglandin J2 induces apoptosis in human malignant B cells: an effect associated with inhibition of NF-kappa B activity and down-regulation of antiapoptotic proteins. Blood 2005, 105(4): 1750-1758.

43. Lo Verme J, Fu J, Astarita G, La Rana G, Russo R, Calignano A, Piomell $D$ : The nuclear receptor peroxisome proliferator-activated receptor-alpha mediates the anti-inflammatory actions of palmitoylethanolamide. Mol Pharmacol 2005, 67(I):15-19.

44. Grommes C, Landreth GE, Heneka MT: Antineoplastic effects of peroxisome proliferator-activated receptor gamma agonists. Lancet Oncol 2004, 5(7):419-429.

45. Granlund L, Larsen LN, Nebb HI, Pedersen Jl: Effects of structural changes of fatty acids on lipid accumulation in adipocytes and primary hepatocytes. Biochim Biophys Acta 2005, 1687(I3):23-30.

Publish with Bio Med Central and every scientist can read your work free of charge

"BioMed Central will be the most significant development for disseminating the results of biomedical research in our lifetime. "

Sir Paul Nurse, Cancer Research UK

Your research papers will be:

- available free of charge to the entire biomedical community

- peer reviewed and published immediately upon acceptance

- cited in PubMed and archived on PubMed Central

- yours - you keep the copyright
BioMedcentral 